\title{
EFFECT OF DIETARY SELENIUM ENRICHED MICRO-ALGAE SUPPLEMENTATION ON GROWTH PERFORMANCE AND ANTI- OXIDATIVE STATUS OF RABBITS UNDER HIGH AMBIENT TEMPERATURE IN SUMMER SEASON
}

\author{
Fawzia A. Hassan ${ }^{1}$, E. M. Hoballah ${ }^{2}$, M.M. Basyony ${ }^{3}$ and Sh. A. El-Medany ${ }^{4}$ \\ ${ }^{1}$ Department of By-products Utilization Research, Animal Production Research Institute, Agricultural \\ Research Center, Giza, Egypt. E-mail address: fawzia_amer@yahoo.com \\ ${ }^{2}$ Agricultural and Biological Research Division, National Research Centre, Dokki, Cairo, Egypt. \\ ${ }^{3}$ Department of Poultry Nutrition, Animal Production Research Institute, Agricultural Research \\ Center, Egypt.
}

${ }^{4}$ Regional Center for Food and Feed; Agriculture Research Center, Giza, Egypt.

(Received 1/5/2015, Accepted 2/7/2015)

\section{SUMMARY}

$\mathrm{T}$ This study was carried out to investigate the effect of different levels of dietary selenium enriched micro-algae supplementation on growth performance, carcass characteristics, blood biochemical constituents, and anti-oxidative status of rabbits under Egyptian summer conditions. Total of 90 male growing New Zealand White rabbits, six weeks old with an average initial body weight $757.5 \mathrm{~g}$ were used in this study. Rabbits were randomly allocated to six experimental groups, with 15 rabbits in each group. The first was a control group, the other five groups offered feed containing, 0.05, 0.1, 0.2, 0.4 and $0.5 \mathrm{mg}$ Sealgae $/ \mathrm{kg}$ diet, respectively. The results showed that final body weight and average body weight gain were not affected $(\mathrm{P}>0.05)$ by selenium enriched micro-algae supplementation. Feed contain Se-algae at $0.2 \mathrm{mg}$ significantly $(\mathrm{P}<0.011)$ improved feed conversion ratio, the best feed conversion ratio $(2.28 \mathrm{~g}$ feed/g gain). Treatment with Se-algae caused significant increase in serum total protein, and globulin concentration while reduce albumin concentration, rabbits fed diet supplemented with 0.1 and $0.2 \mathrm{mg} \mathrm{Se}$-algae were the highest groups in High density lipoprotein (HDL) concentration (55.26 and $54.33 \mathrm{mg} / \mathrm{dl}$, respectively). Dietary treatments with Se-algae significantly $(\mathrm{P}<0.0001)$ reduced total cholesterol, Low density lipoprotein $(\mathrm{LDL})$ and total lipids. There was a significant increase in total antioxidant capacity (TAC), Glutathione Peroxidase (GSH-Px), Superoxide dismutase (SOD) and Catalase (CAT) as Se-algae supplementation increased, additionally, rabbit fed diets supplemented with 0.2 and $0.4 \mathrm{mg}$ Se-algae were the highest in T-AOC, (3.28 and $3.19 \mathrm{mMol} / \mathrm{L}$, respectively). Also, rabbit fed diet supplemented $0.2 \mathrm{mg}$ Se-algae recorded the best serum GSH-Px, SOD and CAT (2.68, 47.04 and $640.67 \mathrm{mU} / \mathrm{ml}$, respectively). Dietary selenium enriched algae significantly $(\mathrm{P}<0.0001)$ reduced thiobarbituric acid reactive substance (TBARS), compared with the control group. As rabbit fed diet supplemented with $0.4 \mathrm{mg}$ Se-algae achieved the best hot carcass weight $(1498.79 \mathrm{~g})$, dressing (63.20\%), edible giblets (3.80\%) and total edible parts (67.02\%). In conclusion, selenium enriched spirulina supplementation improved growth performance, anti-oxidative status and rabbit utilized Se more efficiently in spirulina as organic form of selenium under hot conditions. Accordingly, rabbit meat can be fortified with selenium through dietary supplementation of selenium enriched micro-algae.

Keywords: rabbit, growth, carcass, anti-oxidative status, selenium, algae

\section{INTRODUCTION}

Rabbit meat may be excellent to produce specific functional foods since its good properties such as the fatty acid profile, mineral and vitamin contents which could be further enriched via feeding (Suraï, 2002; Marounek et al., 2009; Dalle Zotte and Szendrö, 2011). Selenium enriched meat could be achieved through the fortification of diets with organic Se (selenomethionine) as it is incorporated into proteins in place of methionine (Rayman, 2004). In fact, Selenium (Se) is a trace element known to play a pivotal role in the antioxidant defense system, protecting the animal from oxidative stress (Zoidis et al., 2010). Moreover, Se is a cofactor of glutathione peroxidase, the enzyme that catalyzes the degradation of peroxides (Castellini et al., 2002; Attia et al., 2010). Reactive oxygen and nitrogen species can cause cell 


\section{Hassan et al.}

damage in animal tissues in cases where antioxidant enzymes are deficient. Selenium plays an important role in activating the antioxidative properties via its involvement in the active site of the enzyme glutathione peroxidase (GSH-Px) in blood, liver and edible tissues (Suraï, 2002) which might be connected with enhancing the immune response in mammals (Rayman, 2004).

Rabbits are particularly sensitive to heat. As a consequence, exposure to temperatures outside the limits of their thermo neutral zone commonly impairs the growth of the animals as well as their reproductive in summer time. Environmental temperatures above $28{ }^{\circ} \mathrm{C}$ cause heat-induced physiological stress. (Marai et al., 2002). It has been shown that the main advantage of organic Se in poultry and animal production is related to its ability to build Se reserves in the body in the form of Selenium methionine which can be used in times of stress to help additional Se-protein production and increased resistance to stress (Suraï and Fisinin, 2014). Moreover, organic Se is a highly available form of Se for livestock and provides antioxidant protection at a level greater than inorganic Se (Mahan, 1999; Mahmoud and Edens, 2003; Al-Waeli et al. 2013).Also, using dietary Se is beneficial to lipid oxidative stability thus preserving meat quality (Liu et al., 2011).

It is necessary to mention that Spirulina (Atrhrospira platensis) is a rich source of phycocyanin, as antioxidant biliprotein pigmentand carotenoids (Cheong et al. 2010). However, scientific information available on performance and antioxidative status in rabbits fed combinations of algae and Se are still limited.

In view of these facts, the present study was conducted on growing rabbits to study the effect of dietary selenium enriched micro-algae Spirulina (Atrhrospira platensis) supplementation on growth performance, carcass characteristics, blood biochemical constituents, and antioxidative status, under Egyptian summer condition.

\section{MATERIALS AND METHODS}

\section{Animals and housing:}

The trial was carried out at Borg-El Arab, Alexandria Governorate, Experimental Station of Animal Production, Animal Production Research Institute, Agricultural Research Center, Ministry of Agriculture, Egypt. Ninety (6 weeks of age) New Zealand White male rabbits were divided randomly into six homogeneous groups ( $\mathrm{n}=15 \mathrm{each})$ with $757.53 \mathrm{~g}$ average live body weight. Animals were housed individually in stainless steel cages $\left(35 \times 35 \times 60 \mathrm{~cm}^{3}\right)$ provided with feeders and automatic nipple drinkers. Diet and water were offered ad libitum. The experimental period was from May to July, 2014. Temperatures were ranged between $28.5-32.5^{\circ} \mathrm{C}$, relative humidity $62-75 \%$ and temperature humidity index (THI) was 87.53-92.99.

\section{Feeding:}

The basal diet was formulated to meet recommended nutrient requirements of growing rabbits according to Lebas (2004). Ingredient and chemical composition of the basal diet are presented in Table (1). Treatment groups were the control (basal diet without any supplementation) and the other five experimental groups (I, II, III, IV and V) which were supplemented by algae at $0.05 ; 0.1 ; 0.2 ; 0.4$ and 0.5 $\mathrm{g} / \mathrm{kg}$ diet, respectively. (Algae containing $1 \mathrm{mg} \mathrm{Se} / \mathrm{g}$ algae). Diets groups I, II, III, IIII and V containing $0.05 ; 0.1 ; 0.2 ; 0.4$ and $0.5 \mathrm{mg}$ Se-alga / $\mathrm{kg}$ diet, respectively. The control diet, thus containing only the endogenous Se contained in the ingredients of the diet. Control was the basal diet containing $0.08 \mathrm{mg}$ $\mathrm{Se} / \mathrm{kg}$ diet.

\section{Microbiological preparation:}

\section{Cyanobacterial strains:}

Three strains of Spirulina platensis (Arthrospira platensis) were obtained from Agric. Microbiology Dept. National Research Centre (NRC), Giza, Egypt, isolate strain NRC1 that isolated from Manzala lake at northeast of Egypt, isolate strain NRC2 that isolated from Burulus lake at north of Egypt and genetically identified strain NRC3 that isolated from Wadi El-Natrun, at Northwest of Egypt (Hoballah et al. 2012). 
Egyptian J. Nutrition and Feeds (2015)

Table (1): Feed ingredients and chemical analysis of basal diet (\%DM basis).

\begin{tabular}{llll}
\hline Feed Ingredient & $(\%)$ & Chemical analysis (\%DM basis) & \\
\hline Soybean meal (44\% CP) & 20.9 & Dry matter (DM) & 87.88 \\
Barley & 32.0 & Organic matter (OM) & 90.88 \\
Wheat bran & 9.20 & Crude protein (CP) & 17.56 \\
Clover hay & 31.0 & Crude fiber (CF) & 13.26 \\
Molasses & 3.00 & Ether extract (EE) & 1.980 \\
Limestone & 0.70 & Nitrogen free extract (NFE) & 58.08 \\
Di- calcium phosphate & 2.20 & Ash & 9.120 \\
DL-Methionine & 0.40 & Methionine & 0.670 \\
Sodium chloride & 0.30 & Methionine+cysteine & 0.760 \\
Vit.-Min. premix & 0.30 & Lysine & 0.980 \\
Total & 100 & Calcium & 1.290 \\
& & Available Phosphours & 0.510 \\
& & Digestible energy (Kcal/Kg DM) & 2790 \\
& & Selenium (mg/kg DM) & 0.08 \\
\hline
\end{tabular}

${ }^{a}$ Mineral and vitamin mixture supplied per $\mathrm{kg}$ of diet: Vitamin A 10,000 IU, Vitamin D3,1,800 UI; Vitamin E, 15 mg; vitamin K3, 4.5 mg; Vitamin B1, 0.5 mg; Vitamin B2, $4 \mathrm{mg}$; Vitamin B12, $0.001 \mathrm{mg}$; Folic acid, $0.1 \mathrm{mg}$; Pantothenic acid, $7 \mathrm{mg}$; Nicotinic acid, $20 \mathrm{mg}$; I, $1 \mathrm{mg}$; Mn, $60 \mathrm{mg}$; Cu, $5.5 \mathrm{mg}$, Zn, $75 \mathrm{mg}$; Fe, $40 \mathrm{mg}$; Co, $0.3 \mathrm{mg}$; Robenidine, $52.8 \mathrm{mg}$.

\section{Selection of alga used for selenium enrichment process:}

For obtaining selenite resistant algal strain that used for selenium enrichment process in raceway ponds, in lab experiment, selenium was added, as sodium selenite, at a concentration of $25 \mathrm{mg} \mathrm{Se}$ $\mathrm{L}^{-1}\left(54.762 \mathrm{mg} \mathrm{L}^{-1}\right.$ of $\left.\mathrm{Na}_{2} \mathrm{SeO}_{3} 172.96 \mathrm{~g} \mathrm{Mol}^{-1}\right)$ in 3 replicates to Erlenmeyer flasks $250 \mathrm{ml}$ contained 150 $\mathrm{ml}$ of modified BG 11 medium for growing the tested cyanobacterial three strains NRC1, NRC2 and NRC3 for obtaining the more selenite resistant strain of them that required for producing selenium enriched cyanobacterium alga (Cases et al., 2002 and Huang et al., 2006).The initial $\mathrm{pH}$ of the medium was set at 9.5, and no adjustments were made throughout the cultivation process. The cultures were incubated in incubator shaker at $60 \mathrm{rpm}$ under light regime at $16 \mathrm{~h}$. day and $8 \mathrm{~h}$. night for 3 weeks (illuminated by Tungsram Lamp F18W/74-765 daylight 950 Lumen) at temperature of $28^{\circ} \mathrm{C}$ (Hoballah et al., 2012). Finally, we selected the strain able to grow on selenite Se that gave the most strain enriched in total selenium content; high chlorophyII content and growth yield (Cases et al., 2002).

\section{Algal fortification in lab and raceway ponds:}

The selected cyanobacterium S. platensis (Arthrospiraplatensis) from National Research Centre (NRC, Cairo, Egypt) is commercialized grown for 25 days by the company El-Nabarawy (El-Farafra Oasis, Al-Wadi Al-Jadid governorate) that has raceway ponds ( 2 meter width * 20 meter length * 0.6 meter depth) with paddle wheel as stirring system with speed of $40 \mathrm{rpm}$, algal separating unit (GEA Westfalia centrifugal Separator- GEA Mechanical Equipment Canada, Inc.) and finally algal drying unit that was local hot air $\left(60^{\circ} \mathrm{C}\right)$ shelved drying pox. Modified medium containing some chemicals in commercial grade was used for growing alga under study (Raoof et al., 2006, Xin et al., 2010, Hoballah et al., 2012 and Arumugam et al., 2013). BG-11 culture medium modified by the addition of $2.0 \mathrm{~g} \mathrm{~L}-1$ $\mathrm{NaHCO}_{3}$ was selected and prepared for the growing cyanobacterium Spirulina platensis without adding citric acid as carbon source and some elements that replaced by commercial grade chemical of super phosphate $\left(1.25 \mathrm{~g} \mathrm{l}^{-1}\right)$, Urea $46.5 \% \mathrm{~N}\left(32.1 \mathrm{mgL}^{-1}\right)$ was added instead of sodium nitrate as nitrogen and carbon sources, Potassium chloride $\left(0.98 \mathrm{~g} \mathrm{l}^{-1}\right)$, Sodium chloride $\left(0.5 \mathrm{~g} \mathrm{l}^{-1}\right)$, Magnesium sulphate $\left(0.15 \mathrm{~g} \mathrm{l}^{-}\right.$ $\left.{ }^{1}\right)$, Calcium chloride $\left(0.04 \mathrm{~g} \mathrm{l}^{-1}\right)$, and Sodium bicarbonate $5 \mathrm{~g} \mathrm{l}^{-1}$. The water used was drinking water well described by Aly (2014) in Table (2) and the raceway location's temperature was $32^{\circ} \mathrm{C}$ in March 2014.

Finally, sodium selenite was added before inoculation process to raceway water at concentration of 25 $\mathrm{mg} \mathrm{Se} \mathrm{L} \mathrm{L}^{-1}\left(54.762 \mathrm{mg}\right.$. L ${ }^{-1}$ of sodium selenite $\left[\mathrm{Na}_{2} \mathrm{SeO}_{3}\right] 172.96 \mathrm{~g}$. $\mathrm{Mol}^{-1}$ ). The initial $\mathrm{pH}$ of the medium was set at 9.5 , and no adjustments were made throughout the cultivation process. Polyethylene bags containing $10 \mathrm{~L}$ of grown alga in BG-11 modified medium were used as raceway algal inoculants, aeration was continuously to bags used for growing alga provided from compressed air from the tube end, then incubated under light regime at $16 \mathrm{~h}$. day and $8 \mathrm{~h}$. night for 3 weeks (illuminated by Tungsram Lamp F18W/74-765 daylight 950 Lumen) at the raceway location's temperature that was $32^{\circ} \mathrm{C}$. 


\section{Hassan et al.}

Table (2): Description of Farafra oasis groundwater chemical composition (Aly, 2014).

\begin{tabular}{|c|c|c|c|c|c|c|c|c|c|c|c|}
\hline \multirow{2}{*}{ Item } & \multirow[t]{2}{*}{$\mathrm{pH}$} & \multirow{2}{*}{$\begin{array}{c}\mathrm{EC} \\
(\mathrm{dS} / \mathrm{m})\end{array}$} & \multicolumn{4}{|c|}{ Cations (milli eyquivalent /L) } & \multicolumn{4}{|c|}{ Anion (milli equivalent/L) } & \multirow[t]{2}{*}{$\begin{array}{c}\mathrm{TDS} \\
(\mathrm{mg} / \mathrm{L}) \\
\end{array}$} \\
\hline & & & $\mathrm{Ca}++$ & $\mathrm{Mg}++$ & $\mathrm{Na}+$ & $\mathrm{K}+$ & $\mathrm{CO}_{3}^{-}$ & $\mathrm{HCO}_{3}{ }^{-}$ & $\mathrm{Cl}^{-}$ & $\mathrm{SO}_{4}^{--}$ & \\
\hline Mean values & 7.2 & 0.2 & 1.1 & 1.1 & 0.7 & 0.4 & 0.0 & 1.1 & 1.8 & 0.4 & 157.9 \\
\hline
\end{tabular}

\section{Algal growth estimation:}

Algal growth was estimated by measuring algal biomass (dry weight basis $\mathrm{g} / 100 \mathrm{ml}$ ) by drying algal growth yield at $60^{\circ} \mathrm{C}$ in oven over night and chlorophyll was estimated by acetone using spectrophotometer method (El-Sayed et al., 2011, Lee et al. 1995 and APHA, 1998).

\section{Prepared algal dried yield:}

The company El-Nabarawy (El-Farafra Oasis, Al-Wadi Al-Jadid governorate) mentioned above, collected selenium enriched cyanobacterium growth from raceway ponds after 20-25 days by using the aforementioned commercial separating centrifuge and then the cyanobacterium yield was dried using hot air $\left(60^{\circ} \mathrm{C}\right)$ in aforementioned shelved drying pox.

\section{Growth performance:}

The rabbits were individually weighed at the beginning and the end of the experiment. Weighing was carried out before the morning feeding. Rabbits were fed individually and feed consumption was recorded so, weight gain and feed conversion ratio were easily calculated.

\section{Slaughter traits:}

At the end of the experimental period (14weeks old), 5 rabbits from each treatment were randomly kept off feed for $12 \mathrm{~h}$, weighed and slaughtered for carcass characteristics and meat analysis. Slaughter procedure and carcass analysis were carried out as described by Blasco and Ouhayoun (1996). After complete bleeding, the skin, viscera and tail were removed and the hot carcasses and its components were weighed as edible parts (liver, kidneys and heart) and the non edible parts including lung, spleen, stomach, large intestine, small intestine were also weighed. Dressing percentage was calculated by dividing the hot dressed carcass weight by pre-slaughter weight and expressed as a percentage according to Steven et al. (1981).

\section{Chemical measurements}

Blood samples (5ml from each rabbit) were collected during slaughter to determine blood serum components. Serum was separated by centrifugation at $3000 \mathrm{rpm}$ for $10 \mathrm{~min}$ and stored at $-20^{\circ} \mathrm{C}$ until analyzed. Blood serum total protein, albumin, Triglycerides, total cholesterol, HDL- cholesterol and LDL-cholesterol. Triglycerides were colormetrically determined using commercial kits (Stanbio Laboratory, USA) according the manufacturers' instructions. Total cholesterol was estimated according to Richmond (1973). Serum total protein was determined according to Orsonneau et al. (1989). Triglycerides were determined accoding to Wahlefeld et al. (1974).

Globulins values were obtained by subtracting albumin values from total protein values. Lipid peroxidation in blood serum was measured in the form of thiobarbituric acid reactive substance (TBARS) as described by Richard et al. (1992). The activity of the antioxidative enzyme Glutathione Peroxidase (GSH-Px) and total antioxidant capacity (T-AOC) of blood serum were measured according to Paglia and Valentine (1967) and Koracevic et al. (2001), respectively, using kits produced by Bio- Diagnostic, Egypt. Superoxide dismutase (SOD) activity was assayed according to Misra and Fridovich (1972) and Catalase (CAT) activity was measured according to Aebi (1984). Selenium concentrations in diets and meat were analyzed by the method of Brown and Watkinson (1977) using a semi-automated fluorometer. Chemical analyses of the experimental diets, spirulina and hind leg meat were carried out according to AOAC (2000) for crude protein (CP), ether extract (EE), crude fiber (CF) and ash. Total selenium determination according to (Shaltout et al., 2013), the analytical procedure was performed using an ICPMS (Perkin Elmer-SCIEX, Thornhill, Canada), the concentration of total selenium was read from the calibration curve.

\section{Statistical analysis}

The differences among experimental groups were statistically analyzed using the General Linear Model procedures of SAS (2001), applying a one-way analysis of variance (ANOVA). The significant 
differences among treatments means of treatments were compared using Duncan's multiple range test (Duncan, 1955).

\section{RESULTS AND DISCUSSION}

\section{Selenium enriched algae cultivation:}

The obtained results from the laboratory experiment in (Table 3) showed that the selected Spirulina platensis strain NRC3 has ability to grow on selenite Se (IV) that considered the most of the tested strains enriched in total selenium content; high chlorophyll content and growth yield. The total selenium content of the selenium enriched Spirulina platensis used in feeding the experimental animals was $1000 \mathrm{mg}$ selenium Se (IV)/kg dried algal weight. The selenate toxicity caused algal cell growth inhibition as well as a block of cell division and bleaching of chloroplasts (Umysová, et al., 2009).

Table (3): Parameters used for selecting from three obtained algae strains that able to be the most strain enriched in total selenium content.

\begin{tabular}{lcccccc}
\hline \multirow{2}{*}{ Parameter used } & \multicolumn{3}{c}{ Non-treated with selenite } & \multicolumn{3}{c}{ Treated with selenite } \\
\cline { 2 - 6 } & NRC1 & NRC2 & NRC3 & NRC1 & NRC2 & NRC3 \\
\hline Chlorophyllmg/g dry weight (fresh alga) & 11.1 & 12 & 12.9 & 9.1 & 8.54 & 12.3 \\
Growth yield g /L dry weight & 0.29 & 0.31 & 0.39 & 0.22 & 0.20 & 0.32 \\
Total selenium mg/kg dry weight & 0.6 & 0.4 & 1.3 & 659.9 & 720 & 1000 \\
\hline
\end{tabular}

The chemical composition of Spirulina was presented in Table (4). It could be noticed that crude protein was lower than the values reported by Kulpys et al. (2009) who found that total protein was (54 vs. $65 \mathrm{~g} / 100 \mathrm{DW}$, respectively). However, Ether extract $(6.70 \%)$ was higher than the value reported by Kulpys et al. (2009). In addition, Zahroojian et al., (2013) reported that Spirulina had protein within range of (55-69\%), carbohydrates (15-25\%), fats (5-6\%) and minerals (6-9\%). In this connection, Indira and Biswajit (2012) reported that microalgae can be used to produce a wide range of metabolites such as proteins, lipids, carbohydrates, carotenoids or vitamins for health, food and feed additives. Nowadays, there are numerous commercial applications of micro algae can be used to enhance the nutritional value of food and animal feed owing to their chemical composition.

Table (4): Chemical composition of Spirulina platensis (\%DM basis).

\begin{tabular}{lccccccc}
\hline Item $(\%)$ & DM & OM & CP & CF & EE & NFE & Ash \\
\hline Spirulina platensis & 85.01 & 94.00 & 54.0 & 3.50 & 6.70 & 25.60 & 10.2 \\
\hline
\end{tabular}

This research work has demonstrated that adding sodium selenite to the culture media of Spirulina platensis, led to enhance the growth rate and magnitude of organic selenium content. This also suggests that a selenium enriched feed with notable market value may be produced efficiently as a Spirulina powder as well as selenium enriched protein, lipids and polysaccharides and other components.

\section{Growth Performance:}

The effect of dietary Se-algae supplementation on growth performance of growing rabbits is presented in Table (5). Supplemented dietary Se-algae significantly $(\mathrm{P}<0.0037)$ increased body weight at 8 week and 10 week at levels of $0.05,0.4 \mathrm{mg} \mathrm{Se}$-algae, respectively compare to the control group. However, body weight at 12 and 14 week of age were not affected by Se-algae supplementation at each tested level. In addition, dietary Se-algae increased $(\mathrm{P}<0.0001)$ body weight gain at $(6-8$ week) compare to the control group. Also supplementation of 0.1 and $0.5 \mathrm{mg}$ Se-algae increased body weight gain at (12-14 week) compare to the control group. While, no significant differences were observed in body weight gain among rabbits groups fed Se-algae diets and the control diet at (8-10 weeks) and (10-12week). Concerning to feed intake, feeding growing rabbits on 0.2 and $0.4 \mathrm{mg}$ Se-algae diets significantly $(\mathrm{P}<0.0011)$ decreased the average feed intake compared to the control group at 12-14 week of age. However, there insignificant differences in average feed intake among rabbit groups fed the tested diets (included control group). 


\section{Hassan et al.}

Results demonstrated that there were significant effects on FCR at (6-8 week), (8-10 week) and (12-14 weeks). Moreover, no significant effect was found on FCR at (10-12 week).

Table (5): The effect of different levels of dietary Se-algae on the growth performance of experimental rabbits $(n=15)$.

\begin{tabular}{|c|c|c|c|c|c|c|c|c|}
\hline \multirow[t]{2}{*}{ Item } & \multicolumn{6}{|c|}{ Se-algae supplementation (mg/kg DM) } & \multirow[t]{2}{*}{ SEM } & \multirow{2}{*}{$\begin{array}{c}\mathrm{P} \\
\text { value }\end{array}$} \\
\hline & Control & 0.05 & 0.1 & 0.2 & 0.4 & 0.5 & & \\
\hline \multicolumn{9}{|l|}{ Average body } \\
\hline weight, g & 760.40 & 762.67 & 759.67 & 758.33 & 752.07 & 752.27 & 27.10 & NS \\
\hline at 6 week & $1006.00^{\mathrm{b}}$ & $1167.47^{\mathrm{a}}$ & $1137.20^{\mathrm{a}}$ & $1189.87^{\mathrm{a}}$ & $1178.40^{\mathrm{a}}$ & $1129.53^{\mathrm{a}}$ & 34.02 & 0.0037 \\
\hline at 8 week & $1477.07^{\mathrm{b}}$ & $1622.13^{\mathrm{a}}$ & $1550.20^{\mathrm{ab}}$ & $1598.33^{\mathrm{ab}}$ & $1607.80^{\mathrm{a}}$ & $1551.33^{\mathrm{ab}}$ & 41.30 & 0.05 \\
\hline at 10 week & 1908.79 & 2008.27 & 1984.64 & 2007.60 & 1995.33 & 1976.43 & 46.19 & NS \\
\hline at 12 week & 2252.42 & 2403.64 & 2384.00 & 2337 & 2337.14 & 2381.43 & 55.81 & NS \\
\hline \multicolumn{9}{|l|}{ at 14 week } \\
\hline \multicolumn{9}{|l|}{ Body weight gain, $g$} \\
\hline 6-8 week & $245.60^{\mathrm{b}}$ & $404.80^{\mathrm{a}}$ & $377.53^{\mathrm{a}}$ & $431.53^{a}$ & $426.33^{a}$ & $377.27^{\mathrm{a}}$ & 21.23 & 0.0001 \\
\hline 8-10 week & 471.07 & 454.67 & 413.00 & 408.47 & 429.40 & 421.80 & 28.55 & NS \\
\hline 10-12 week & 431.72 & 386.13 & 434.44 & 409.27 & 387.53 & 425.10 & 23.45 & NS \\
\hline 12-14 week & $343.63^{b}$ & $395.38^{\mathrm{ab}}$ & $399.36^{\mathrm{a}}$ & $329.54^{\mathrm{ab}}$ & $341.81^{\mathrm{ab}}$ & $405.00^{\mathrm{a}}$ & 22.42 & 0.05 \\
\hline \multicolumn{9}{|l|}{ eed Intake, $\mathrm{g}$} \\
\hline $6-8$ week & 492.20 & 476.99 & 443.41 & 455.52 & 485.85 & 459.69 & 15.48 & NS \\
\hline $8-10$ week & 836.36 & 752.37 & 768.35 & 761.25 & 768.41 & 759.02 & 35.16 & NS \\
\hline 10-12 week & 1267.93 & 1220.30 & 1291.16 & 1178.59 & 1154.36 & 1184.55 & 50.73 & NS \\
\hline 12-14 week & $1453.08^{\mathrm{a}}$ & $1375.00^{\mathrm{ab}}$ & $1416.10^{\mathrm{a}}$ & $1102.29^{c}$ & $1235.29^{\mathrm{bc}}$ & $1435.34^{\mathrm{a}}$ & 41.28 & 0.0011 \\
\hline \multicolumn{9}{|l|}{$\mathrm{FCR}, \%^{(1)}$} \\
\hline $6-8$ week & $2.00^{\mathrm{a}}$ & $1.18^{\mathrm{b}}$ & $1.17^{\mathrm{b}}$ & $1.06^{\mathrm{b}}$ & $1.14^{\mathrm{b}}$ & $1.22^{\mathrm{b}}$ & 0.10 & 0.0001 \\
\hline 8-10 week & $1.78^{\mathrm{ab}}$ & $1.65^{b}$ & $1.86^{\mathrm{ab}}$ & $1.86^{\mathrm{a}}$ & $1.79^{\mathrm{ab}}$ & $1.80^{\mathrm{ab}}$ & 0.11 & 0.05 \\
\hline 10-12 week & 2.98 & 3.16 & 2.97 & 2.88 & 2.98 & 2.79 & 0.17 & NS \\
\hline 12-14 week & $4.23^{\mathrm{a}}$ & $3.48^{\mathrm{b}}$ & $3.55^{\mathrm{b}}$ & $3.34^{\mathrm{b}}$ & $3.61^{\mathrm{b}}$ & $3.54^{\mathrm{b}}$ & 0.18 & 0.01 \\
\hline \multicolumn{9}{|c|}{ Duration period, 56 days } \\
\hline Average daily FI, g & $72.31^{\mathrm{a}}$ & $68.29^{\mathrm{ab}}$ & $69.98^{\mathrm{a}}$ & $64.06^{\mathrm{c}}$ & $65.06^{\mathrm{bc}}$ & $68.54^{\mathrm{ab}}$ & 1.46 & 0.0019 \\
\hline Average daily $\mathrm{G}, \mathrm{g}$ & 26.64 & 29.30 & 29.01 & 28.19 & 28.30 & 29.09 & 0.88 & NS \\
\hline Average FCR & $2.73^{\mathrm{a}}$ & $2.36^{\mathrm{b}}$ & $2.38^{\mathrm{ab}}$ & $2.28^{\mathrm{b}}$ & $2.38^{\mathrm{b}}$ & $2.33^{\mathrm{b}}$ & 0.05 & 0.0110 \\
\hline
\end{tabular}

$a, b, c$ and $d:$ Means in the same row having different superscripts differ significantly $(P<0.05), N S=$ not significant.

(1) Feed conversion ratio $(F C R)=$ feed intake $(\mathrm{kg}) /$ body weight gain $(\mathrm{kg})$.

During the experiment period, it was shown that Se-algae supplementation reduced daily feed intake compared with the control group, and there were significant differences in average feed intake between the control group and rabbits fed diets supplemented with 0.2 and $0.4 \mathrm{mg} \mathrm{Se}$ - algae. Also, rabbit fed diet supplemented with $0.2 \mathrm{mg}$ Se-algae recorded the lowest feed intake $(64.06 \mathrm{~g} / \mathrm{d})$, while the control group was the highest group $(72.31 \mathrm{~g} / \mathrm{d})$ in feed intake. No significant $(\mathrm{P}>0.05)$ effect of Se-algae on average body weight gain was observed during the experimental period. While rabbit fed diet supplemented with $0.05 \mathrm{mg}$ Se-algae was the highest group in daily gain $(29.30 \mathrm{~g} / \mathrm{d})$ followed by rabbit fed diet supplemented with $0.5 \mathrm{mg}$ Se-algae $(29.09 \mathrm{~g} / \mathrm{d})$ and rabbit fed diet supplemented with $0.1 \mathrm{mg}$ Se-algae $(29.01 \mathrm{~g} / \mathrm{d})$. While, the lowest one was the rabbit fed diet supplemented with $0.2 \mathrm{mg}$ Se-algae $(28.19 \mathrm{~g} / \mathrm{d})$. Supplementation with Se-algae significantly improved FCR, as well as there were significant $(\mathrm{P}<0.011)$ differences in average FCR between the control group and all the rabbit fed diets supplemented with Sealgae. The best FCR (2.28 g feed/g gain) was achieved when the dietary Se-algae supplementation was $0.2 \mathrm{mg}$ Se-algae.

The results of present study clearly indicated that dietary supplementation of Se-algae at $0.05,0.1,0.2$, 0.4 and $0.5 \mathrm{mg} \mathrm{Se}$-algae had a positive effect on growth performance of growing rabbits. Similar results were observed by (Ebeid et al., 2013) who found that Se addition at $0.3 \mathrm{mg}$ organic Se/kg diet resulted increased the final body weight, daily gain while feed conversion ratio was reduced in the growing rabbits. Saleh et al. (2013) reported that Linseed oil plus $0.3 \mathrm{ppm}$ organic selenium increased body weight gain significantly $(\mathrm{P}<0.05)$ while reduced significantly $(\mathrm{P}<0.05)$ feed intake. Likewise, Zhang et al. (2011) reported that the dietary Se level significantly affected average daily gain and feed/ gain ratio in 
meat rabbits from weaning to 2 months old, the group of rabbits fed with the diet of $0.24 \mathrm{mg} / \mathrm{kg} \mathrm{Se}$ showed significant improvement of body weight gain and feed conversion efficiency. However, the level of dietary Se had no significant effect on the average feed intake $(\mathrm{P}>0.05)$ of the rabbits. As well as better daily gain and feed/gain ratio were achieved when the dietary Se level was more than $0.24 \mathrm{mg} / \mathrm{kg}$. Moreover, dietary organic Se improved body weight and feed conversion ratio of broiler chicken (Wang and $\mathrm{Xu}, 2008)$. A potential reason for this may be the profile of organic compounds of Se in the Se-algae (Larsen et al. 2001). These compounds act as natural antioxidants and can protect mucosa against oxidative damage and pathogens so, it prevents diarrhea (Kermauner and Laurencic, 2008). In addation, and also organic Se build Se reserves in the body in the form of Se Met which can be used in times of stress to help additional Se-protein production and increased resistance to stress (Fisinin et al. 2008; Surai, and Fisinin, 2014). Selenium as a part of various selenoproteins can help maintain antioxidant defenses preventing damages to tissues and affectively respond to environmental changes (Surai and Fisinin., 2014). Also, Yang et al. (2012) stated that the beneficial nutrient utilization due to the positive effects of Se is its role as an antioxidant agent which protect nutrients from oxidation particularly vitamin $\mathrm{A}$ and $\mathrm{D}_{3}$. Selenium has important biological functions and is an essential element for animal growth. Selenium is an important auxiliary factor for the key enzyme of $5^{\prime}$-deiodinase, which synthesizes triiodothyronine (T3) in animals. Triiodothyronine is a main hormone that regulates animal growth by controlling the body's energy and protein anabolism. Se deficiency can cause the reduction of T3 synthesis and growth inhibition (Preter, 2000). On the contrary, Marounek et al. (2009) did not show significant effect of Se supplementats on rabbit growth, feed intake and feed conversion. Moreover, Dokoupilová et al. (2007) confirmed that no effect of Se at $0.50 \mathrm{mg} / \mathrm{kg}$ was observed on growth and feed conversion. Abdel-Khalek et al. (2013) stated that total weight gain and feed conversion were not affected significantly by dietary Se levels (zero, $0.05,0.1,0.2,0.4$ and $0.8 \mathrm{mg} / \mathrm{kg}$ diets). Although, feed intake was significantly $(\mathrm{P}<0.05)$ affected especially with feeding the highest dietary Se level. These results are in correspondence with other authors in Lambs (Antunović et al., 2014) and chicken (Payne and Southern, 2005; Spears et al., 2003).

\section{Blood constituents:}

The effects of dietary Se-algae supplementation levels on blood constituents of growing rabbits are presented in Table (6). The results of present study demonstrated that dietary Se-algae supplementation caused a significant increase in total protein and globulin while decrease albumin concentration and A/G ratio when compared with the control group. Supplementation of Se-algae at $0.1 \mathrm{mg}$ was the highest $(\mathrm{P}<0.05)$ group in total protein and globulin $(7.06$ and $3.75 \mathrm{~g} / \mathrm{dl})$. These findings are similar to Ebeid et al. (2013) who stated that dietary treatment with organic Se at $0.3 \mathrm{mg} / \mathrm{kg}$ diet increased globulin concentration and found that globulin findings were in agreement with immune responses.

The results of this study showed an increase in total protein and globulin which may be partly due to Se-algae supplementation. In this connection, McConnell and Hoffman (1972) demonstrated that selenomethionine was incorporated into liver polypeptides via the methionine pathway. Furthermore, Selenium is present in two biologically active forms, Se-containing enzymes and Se-containing proteins in animals (Zhang et al., 2011). While, the control group without the supplementation of Se-algae had the lowest total protein and globuin, this reduction might be due to oxidative damage in proteins ranges from specific amino acid modifications and peptide breakage to loss of enzyme activity (Stadtman and Levine, 2003). Little information on the selenium form in Se-enriched Spirulina is available for the time being. Selenium is assumed to be built into the protein structure similarly like it is into Se-enriched yeast (Machat et al., 2005), so Se-enriched spirulina may be used as a potential form of organic selenium supplemented to sows diets (Kotrbaček et al., 2004).

Se-algae supplementation reduced plasma triglycerides content compared with the control group. Rabbit fed diet supplemented with $0.2 \mathrm{mg} \mathrm{Se}$-algae was the lowest group in triglycerides content (41.84 $\mathrm{mg} / \mathrm{dl}$ ). Similarly, Ebied et al. (2012) stated that rabbit fed diets supplemented with 0.15 or $0.3 \mathrm{ppm}$ organic Se significantly reduced triglycerides. While, dietary treatments with Se-algae significantly reduced cholesterol, LDL and total lipid compared with the control group. Dietary supplementation with $0.5 \mathrm{mg}$ Se-algae was the lowest in cholesterol.

Concerning to HDL concentration, there was a significant increase $(\mathrm{P}<0.05)$ as Se-algae supplementation increased. Rabbits fed diet supplemented with 0.1 and $0.2 \mathrm{mg}$ Se-algae were the highest groups in HDL concentration $(55.26,54.33 \mathrm{mg} / \mathrm{dl}$, respectively), while the control group was the lowest one (44.10 mg/dl). In agreement with our results, Ryu et al. (2005) used $8 \mathrm{mg} \mathrm{Se} / \mathrm{kg}$ DM in broiler diet and reported that the cholesterol concentration was reduced. This result was in accordance with Colla $e t$ al. (2008) who observed that the serum levels of HDL-cholesterol were higher in the rabbit fed with Spirulina. These results showed the potential of biomass Spirulina to decrease the serum levels of total 


\section{Hassan et al.}

cholesterol. In addition, Cheong et al. (2010) reported that spirulina intake can cause the reduction of total triglycerides, total cholesterol and LDL-cholesterol and an elevation of HDL-cholesterol level. In the contrast, Ebeid et al. (2013) postulated that dietary treatments with Se at $0.3 \mathrm{mg} / \mathrm{kg}$ diet did not modify serum total cholesterol, LDL-cholesterol, HDL-cholesterol, triglycerides, total protein or albumin. Additionally, Ebeid et al. (2012) found that the dietary treatment with organic Se did not affect total cholesterol content, LDL-cholesterol, total protein and albumen in serum while serum triglycerides and globulins were significantly affected.

These findings suggested that dietary Se-algae supplementation reduced the plasma lipid concentration, although there are limited cases of studies that show direct evidence of the efficacy of Sealgae. These results may be related to effect of Se as it has an anabolic role on fat deposition. The effects of this supplementation were to modulate fatty acid composition in the whole body. Or, these alterations could be due to The Spirulina components such as polyunsaturated fatty acids, phycocyanin which are thought to be compounds with antioxidant abilities according to Nagaoka et al. (2005).

Table (6): Effect of dietary Se-algae supplementation on blood constituents.

\begin{tabular}{|c|c|c|c|c|c|c|c|c|}
\hline \multirow[t]{2}{*}{ Item } & \multicolumn{6}{|c|}{ Se-algae supplementation (mg/kg DM) } & \multirow[b]{2}{*}{ SEM } & \multirow[b]{2}{*}{$\begin{array}{l}\mathrm{P} \\
\text { value }\end{array}$} \\
\hline & Control & 0.05 & 0.1 & 0.2 & 0.4 & 0.5 & & \\
\hline Total Protein $(\mathrm{g} / \mathrm{dl})$ & $5.63^{\mathrm{c}}$ & $6.55^{b}$ & $7.06^{\mathrm{a}}$ & $6.81^{\mathrm{ab}}$ & $6.6^{\mathbf{b}}$ & $6.65^{b}$ & 0.16 & 0.0002 \\
\hline Albumin $(\mathrm{g} / \mathrm{dl})$ & 3.3 & 3.22 & 3.30 & 3.18 & 3.01 & 3.02 & 0.10 & NS \\
\hline Globulin (g/dl) & $2.33^{\mathrm{c}}$ & $3.33^{\mathrm{b}}$ & $3.75^{\mathrm{a}}$ & $3.613^{\mathrm{ab}}$ & $3.59^{\mathrm{ab}}$ & $3.63^{\mathrm{ab}}$ & 0.19 & 0.0001 \\
\hline $\mathrm{A} / \mathrm{G}$ ratio & $1.22^{\mathrm{a}}$ & $0.96^{\mathrm{ab}}$ & $0.88^{\mathbf{b}}$ & $0.87^{\mathbf{b}}$ & $0.83^{\mathrm{c}}$ & $0.83^{\mathrm{c}}$ & 0.09 & 0.0194 \\
\hline Triglycerides (mg/dl) & $61.50^{\mathrm{a}}$ & $45.74^{\mathrm{b}}$ & $42.90^{\mathrm{b}}$ & $41.84^{\mathrm{b}}$ & $43.84^{\mathrm{b}}$ & $42.23^{\mathrm{b}}$ & 6.06 & 0.05 \\
\hline $\begin{array}{l}\text { Total Cholesterol } \\
(\mathrm{mg} / \mathrm{dl})\end{array}$ & $100.21^{\mathrm{a}}$ & $93.24^{\mathbf{b}}$ & $92.17^{\mathbf{b}}$ & $90.79^{\mathbf{b}}$ & $91.91^{\mathbf{b}}$ & $88.71^{\mathbf{b}}$ & 1.60 & 0.0001 \\
\hline $\begin{array}{l}\text { HDL- cholesterol } \\
(\mathrm{mg} / \mathrm{dl})\end{array}$ & $44.10^{\mathbf{b}}$ & $51.93^{\mathrm{ab}}$ & $55.26^{\mathrm{a}}$ & $54.33^{\text {ab }}$ & $51.78^{a b}$ & $53.62^{\mathrm{ab}}$ & 3.17 & 0.196 \\
\hline $\begin{array}{l}\text { LDL- cholesterol } \\
(\mathrm{mg} / \mathrm{dl})\end{array}$ & $47.02^{\mathrm{a}}$ & $34.07^{\mathbf{a b}}$ & $32.91^{\text {ab }}$ & $33.73^{a b}$ & $32.41^{\mathrm{b}}$ & $30.85^{\mathbf{b}}$ & 1.78 & 0.270 \\
\hline Total Lipid (mg/l) & $374.09^{a}$ & $322.69^{\mathbf{a b}}$ & $267.62^{\mathbf{b}}$ & $299.32^{\mathbf{b}}$ & $317.10^{\mathbf{a b}}$ & $270.84^{b}$ & 17.34 & 0.0071 \\
\hline
\end{tabular}

$a, b, c:$ Means in the same row having different superscripts differ significantly $(P<0.05), N S=$ not significant.

\section{blood Serum antioxidative status:}

The effect of Se-algae levels on antioxidantive status of growing rabbits are presented in table (7). Dietary Se-algae supplementation resulted in a significant effect on serum blood antioxidative properties as measured by total antioxidant capacity (T-AOC) and TBARS as an indexes of oxidation and antioxidant enzymes such as glutathione peroxidase (GSH-Px), superoxide dismutase (SOD) and Catalase (CAT). It could be observed that there was a significant increase in TAC, GSH-Px, SOD and CAT as Sealgae level increased. Rabbits fed diets supplemented with 0.4 and 0.2 Se-algae were the highest in TAC, (3.28 and $3.19 \mathrm{mMol} / \mathrm{L}$, respectively). Also, rabbits fed diet supplemented with 0.2 Se-algae recorded the highest GSH-Px, SOD and CAT $(2.68,47.04$ and $640.67 \mathrm{mU} / \mathrm{ml}$, respectively) as compared with the control group. In addition, dietary Se-algae significantly $(\mathrm{P}<0.0001)$ reduced TBARS, compared with the control, rabbits fed diet supplemented with $0.2 \mathrm{mg}$ Se-algae was the lowest $(\mathrm{P}<0.05)$ in TBARS concentration $(2.70 \mathrm{nmol} / \mathrm{l})$ and reduced serum TBARS to level about $57.4 \%$ lower than in the control group. These results are in agreement with Ebeid et al. (2013) demonstrated that dietary Se for growing rabbit resulted in a significant increase of GSH-Px activity and TAC to more than three times the corresponding value of the control. Furthermore, Zhang et al. (2011) stated that the dietary Se level had a cubic relationship with the serum GSH-Px and CAT activities, with the greatest serum GSH-Px and CAT activities observed in the rabbits fed the diet with $0.24 \mathrm{mg} / \mathrm{kg}$ Se. Also, Ebeid et al. (2012) found that inclusion of 0.15 or $0.3 \mathrm{ppm}$ Se in the growing rabbits' diets elevated serum total antioxioxidant capacity and reduced the lipid peroxidation expressed as serum malondialdehyde. Similarly, Ebeid (2009) indicated that serum lipid peroxidation decreased significantly in a dose-dependent manner when dietary organic Se level was increased in cockerels.

These results confirmed that supplementing rabbit diets with Se-algae enhanced the antioxidative status as it is an efficient scavenger of free radicals (McDowell, 1992) stated that Se is an essential constituent of glutathione peroidase (GSH-Px). This enzyme aids in protecting cellular membranes from 
oxidative damage. Several studies showed that increase of (GSH-Px) activity in animal exposed to oxidative stress as a mechanism to ward off lipid peroxidation. (Maraschiello et al., 1999, Dalle Zotte and Szendrö, 2011), reducing lipid peroxidation in serum blood and increasing the antioxidant defense system, which resulted in enhancing growth performance of rabbit under hot conditions. Selenium contributes to the protection of cells from oxidative damage via the activity of GSH-Px, which is an enzyme that catalyzes the reduction of hydrogen peroxide and organic peroxides (Behne et al., 2009). A possible reason for this may be the different profile of organic compounds of Se in the Se-algae (Larsen $e t$ al., 2001). Kim et al., (2010a) suggest that dietary supplementation with Spirulina of New Zealand White rabbit may be useful to protect the cells from lipid peroxidation, oxidative DNA damage and oxidative stress biomarkers such as glutathione, glutathione peroxidase, glutathione reductase, and glutathione $S$ transferase which were significantly improved in the liver.

The T-AOC reflects the total antioxidant capacity of the body. Although, Se is not a component of SOD or CAT, the ability to synthesize various antioxidant enzymes declines under Se-deficient conditions in animals, while the increase of lipid peroxidation affects vitality. Therefore, increases in GSH-Px and CAT activity enhance the ability to eliminate free radicals. A decrease of the MDA content in the tissues is related to the enhancement of antioxidant enzymatic activity that results from the provision of supplemental dietary Se. Improvement in antioxidant capacity is attributed to inducible Se dependent antioxidant enzymes (Suraï, 2002).

It can be concluded that Se-algae supplementation which representing a natural organic bound form enhance antioxidative status and protect the tissues against oxidative damage which included protein and fat oxidation of growing rabbit under hot conditions. A reduction in oxidation level by inclusion of selenium enriched algae into the diets was observed and was associated with the higher activity of glutathione peroxidase, SOD and catalase.

Table (7): Effect of dietary Se-algae supplementation on antioxidative status of serum.

\begin{tabular}{|c|c|c|c|c|c|c|c|c|}
\hline \multirow{2}{*}{ Item } & \multicolumn{6}{|c|}{ Se-algae supplementation (mg/kg DM) } & \multirow[b]{2}{*}{ SEM } & \multirow[b]{2}{*}{ P-value } \\
\hline & Control & 0.05 & 0.1 & 0.2 & 0.4 & 0.5 & & \\
\hline $\begin{array}{l}\text { T-AOC } \\
(\mathrm{mMl} / \mathrm{L})\end{array}$ & $0.60^{\mathrm{d}}$ & $0.93^{\mathrm{cd}}$ & $1.16^{\mathrm{c}}$ & $3.19^{\mathrm{a}}$ & $3.28^{\mathrm{a}}$ & $2.04^{\mathrm{b}}$ & 0.098 & 0.0001 \\
\hline $\begin{array}{l}\text { TBARS }^{b} \\
(\mathrm{nmol} / \mathrm{l})\end{array}$ & $6.34^{\mathrm{a}}$ & $6.01^{\mathrm{b}}$ & $2.90^{\mathrm{c}}$ & $2.70^{c}$ & $2.75^{\mathrm{c}}$ & $2.84^{\mathrm{c}}$ & 0.065 & 0.0001 \\
\hline $\begin{array}{l}\text { GSH-Px }{ }^{\mathrm{C}} \\
(\mathrm{mU} / \mathrm{ml})\end{array}$ & $0.79^{\mathrm{d}}$ & $1.05^{\mathrm{cd}}$ & $1.19^{c}$ & $2.68^{\mathrm{a}}$ & $2.10^{\mathrm{b}}$ & $2.06^{\mathrm{b}}$ & 0.101 & 0.0001 \\
\hline $\mathrm{SOD}^{\mathrm{d}}(\mathrm{U} / \mathrm{l})$ & $27.04^{\mathrm{d}}$ & $31.68^{\mathrm{cd}}$ & $36.08^{\mathrm{bc}}$ & $47.04^{\mathrm{a}}$ & $44.64^{\mathrm{ab}}$ & $38.64^{\mathrm{abc}}$ & 2.475 & 0.0006 \\
\hline $\mathrm{CAT}^{\mathrm{e}}(\mathrm{U} / \mathrm{g})$ & $469.90^{\mathrm{b}}$ & $568.89^{\mathrm{a}}$ & $638.03^{\mathrm{a}}$ & $640.67^{\mathrm{a}}$ & $626.80^{\mathrm{a}}$ & $568.74^{\mathrm{a}}$ & 22.73 & 0.0004 \\
\hline
\end{tabular}

a T-AOC, Total antioxidant capacity, $b$ TBARS, Thiobarbituric acid , c GSH-Px, Glutathione peroxidase, $d$ SOD, Superoxide dismutase, e CAT, Catalase.a, $b, c$ and $d$ : Means in the same row having different superscripts differ significantly

\section{Carcass characteristics:}

Effects of Se-algae supplementation on carcass characteristics are presented in Table (8). The results indicated that supplementation of dietary Se-algae increased hot carcass, dressing (\%), edible giblets(\%), total edible parts $(\%)$ and total non-edible parts (\%) compared to control group with rabbits fed diet supplemented with $0.4 \mathrm{mg} \mathrm{Se}$-algae achieved the best hot carcass weight $(1498.7 \mathrm{~g})$, dressing $(63.2 \%)$, edible giblets (3.80\%) and total edible parts $(67.02 \%)$ and the same group (0.4 $\mathrm{mg} \mathrm{Se}$-algae) was the lowest in total non-edible compared with the other groups.

The results are in agreement with other results that indicated that Se-algae supplementation tended to improve both hot carcass weight and dressing (\%) in rabbits (Ebeid et al., 2013). Also, Eibed et al. (2012) evaluated the inclusion of organic Se in the diets and found that Supplementation with 0.15 and $0.3 \mathrm{ppm}$ organic Se increased both hot carcass weight and dressing percentage in growing rabbits. On the contrary, other studies have found no significant effect of Se-algae supplementation on carcass yield (Dokoupilová et al., 2007). Marounek et al. (2009) reported that no significant difference on hot carcass weight, chilled carcass weight and dressing percentage were observed with different froms of Se-algae supplementation being selenite, Se-yeast and Se-algae. Moreover, Abedel-khalek et al. (2013) stated that carcass traits in terms of hot carcass and dressing percentages were not significantly responded to Se level. 
Table (8): Effect of dietary Se-algae supplementation on carcass characteristics in growing rabbits.

\begin{tabular}{|c|c|c|c|c|c|c|c|c|}
\hline \multirow[t]{2}{*}{ Item } & \multicolumn{6}{|c|}{ Se-algae supplementation (mg/kg DM) } & \multirow[t]{2}{*}{ SEM } & \multirow{2}{*}{$\begin{array}{c}P_{-} \\
\text {value }\end{array}$} \\
\hline & Control & 0.05 & 0.1 & 0.2 & 0.4 & 0.5 & & \\
\hline $\begin{array}{l}\text { Pre-slaughter weight } \\
\text { (g) }\end{array}$ & 2332.2 & 2340.6 & 2413.4 & 2364.0 & 2372.0 & 2339.0 & 62.5 & NS \\
\hline Hot carcass weight $(\mathrm{g})$ & $1340.5^{\mathrm{b}}$ & $1406.5^{\mathrm{a}}$ & $1469.5^{\mathrm{a}}$ & $1450.7^{\mathrm{a}}$ & $1498.7^{\mathrm{a}}$ & $1468.7^{\mathrm{a}}$ & 44.1 & 0.023 \\
\hline Dressing $\%$ & $57.5^{\mathrm{b}}$ & $60.2^{\mathrm{a}}$ & $61.0^{\mathrm{a}}$ & $61.3^{\mathrm{a}}$ & $63.2^{\mathrm{a}}$ & $63.1^{\mathrm{a}}$ & 1.70 & 0.033 \\
\hline Edible Giblets \% & $3.20^{\mathrm{b}}$ & $3.56^{\mathrm{ab}}$ & $3.56^{\mathrm{ab}}$ & $3.62^{\mathrm{ab}}$ & $3.80^{\mathrm{a}}$ & $3.74^{\mathrm{a}}$ & 0.10 & 0.05 \\
\hline Total edible parts $\%$ & $60.7^{\mathrm{b}}$ & $63.76^{\mathrm{a}}$ & $64.56^{\mathrm{a}}$ & $64.92^{\mathrm{a}}$ & $67.02^{\mathrm{a}}$ & $66.76^{\mathrm{a}}$ & 1.80 & 0.016 \\
\hline $\begin{array}{l}\text { Total Non edible parts } \\
\%\end{array}$ & $39.3^{\mathrm{a}}$ & $36.24^{\mathrm{b}}$ & $35.44^{\mathrm{b}}$ & $35.08^{\mathrm{b}}$ & $32.98^{b}$ & $33.24^{\mathrm{b}}$ & 1.79 & 0.028 \\
\hline
\end{tabular}

$a, b$ : Means in the same row having different superscripts differ significantly $(P<0.05), N S=$ not significant.

\section{Chemical composition of meat:}

Results in Table (9) clarify that adding of Se-algae affect significantly on meat composition of (DM, $\mathrm{CP}$, EE, Ash and Se content) of hind leg of rabbits. Se supplementation had no effect on the CP. Regarding to EE, data indicated significantly decrease in supplemented groups than the control group as the supplementation of Se-algae increased. Rabbits fed diets supplemented with $0.5 \mathrm{mg}$ Se-algae was the lowest $(\mathrm{P}<0.0001)$ group in $\mathrm{EE}$. The reduction of EE may well be caused by different components of Sealgae.

Table (9): Effect of dietary Se-algae supplementation on meat chemical composition of growing rabbits.

\begin{tabular}{lcccccccc}
\hline \multirow{2}{*}{ Item } & \multicolumn{9}{c}{ Se-algae supplementation $(\mathrm{mg} / \mathrm{kg}$ DM $)$} & & \\
\cline { 2 - 7 } & Control & 0.05 & 0.1 & 0.2 & 0.4 & 0.5 & SEM & $P$-value \\
\hline Moisture & $72.17^{\mathrm{c}}$ & $72.68^{\mathrm{ab}}$ & $73.36^{\mathrm{a}}$ & $73.08^{\mathrm{a}}$ & $73.03^{\mathrm{a}}$ & $72.93^{\mathrm{a}}$ & 0.186 & 0.0004 \\
$\mathrm{DM}$ & $28.06^{\mathrm{a}}$ & $27.32^{\mathrm{b}}$ & $26.63^{\mathrm{c}}$ & $26.92^{\mathrm{bc}}$ & $26.97^{\mathrm{bc}}$ & $27.07^{\mathrm{bc}}$ & 0.18 & 0.0004 \\
$\mathrm{CP}$ & 22.09 & 22.22 & 22.19 & 22.64 & 22.42 & 22.48 & 0.20 & 0.424 \\
$\mathrm{EE}$ & $4.58^{\mathrm{a}}$ & $3.56^{\mathrm{b}}$ & $2.75^{\mathrm{c}}$ & $2.56^{\mathrm{c}}$ & $2.47^{\mathrm{c}}$ & $2.46^{\mathrm{c}}$ & 0.16 & 0.0001 \\
Ash & $1.39^{\mathrm{b}}$ & $1.53^{\mathrm{ab}}$ & $1.69^{\mathrm{ab}}$ & $1.72^{\mathrm{ab}}$ & $2.08^{\mathrm{a}}$ & $2.16^{\mathrm{a}}$ & 0.21 & 0.0001 \\
$\mathrm{SE}(\mu \mathrm{g} / \mathrm{g})$ & $0.096^{\mathrm{e}}$ & $0.121^{\mathrm{d}}$ & $0.188^{\mathrm{c}}$ & $0.200^{\mathrm{c}}$ & $0.364^{\mathrm{b}}$ & $0.471^{\mathrm{a}}$ & 0.004 & 0.0001 \\
\hline
\end{tabular}

$a, b, c, d$ and $e$ : Means in the same row having different superscripts differ significantly $(P<0.05)$.

These results are consistent with Dalle Zotte et al. (2012) who stated that 5\% Spirulina supplementation seems promising in reducing cholesterol content of fattening rabbit meat, but its inclusion level should be further increased, however, the lipid lowering effect of Spirulina was effective on rabbits fed high fat diets only and not on low fat diet group (Meineri et al., 2009). The effect of Spirulina on metabolism described by several studies, that the properties of Spirulina increases the activity of lipoprotein lipase (Richmond, 1992; Iwata et al., 1990). Additionally, Spirulina was confirmed as a rich source of vitamin B12 that was successfully transferred into Longissimus dorsi (LD) muscle, thus demonstrating its value as an effective natural supplement in producing food fortified with this vital element (Dalle Zotte et al., 2014).

These results are in contrary with data reported by Ebeid et al. (2013) and Ebeid et al. (2012) who found that dietary Se had no significant effect on meat composition. These responses were similar to observation by Marounek et al. (2009) who revealed that Se supplements had no effect on the CP and of hind leg meat of rabbit supplementation with Se-algae and contained less fat than that of control rabbits. Similarly, Dokoupilová et al. (2007) indicated that the content of dry matter in meat was not significantly affected by dietary Se supplementation. There are limited cases of studies that show direct evidence of the efficacy of Se-Spirulina in reducing the fat content of meat composition. 
The present study was revealed that dietary Se-algae supplementation significantly increased $(\mathrm{P}<0.0001)$ Se content and ash content in hind leg. Similar results were reported by Dokoupilová et al. (2007) who found that lion and hind leg meat of rabbit fed the Se-supplemented diet contained four times more Se than meat of control rabbits. Additionally, Marounek et al. (2009) reported that Se concentration in meat increased in rabbits fed diets supplemented with Se-algae in which the Se concentration in meat was doubled. Whereas in poultry, the fortification of diets with selenium $(0.3 \mathrm{ppm})$ increased lipid oxidative stability and delayed microbial growth in the thigh muscle (Kim et al., 2010b). Dalle Zotte and Szendrö (2011) reported that supra-nutritional levels of selenium $(0.5 \mathrm{mg} / \mathrm{kg}$ diet $)$ are able to produce selenium-fortified rabbit meat so as to make a significant contribution to human selenium intake. Additionaly, The organic selenium (Se-algae) is more deposited into the muscle tissue and animal organs than inorganic one (Behne et al., 2009).

\section{CONCLUSION}

It could be suggested that dietary supplementation with selenium enriched micro-algae can improve the body weight gain, feed conversion ratio so it had a beneficial effect on health and overall growth performance in growing rabbits. Dietary Se-algae supplementation reduced the blood lipid concentration. As well as, Se-algae supplementation representing a natural organic bound form which enhances antioxidative status and protects the tissues against oxidative damage of growing rabbit under hot conditions. Moreover, rabbit meat can be fortified with selenium through dietary supplementation of Se-algae.

\section{ACKNOWLEDGEMENTS}

Research funded by Animal Production Research Institute. The authors thank Borg el Arab Experimental Station and National Research Center stuffs for their technical support.

\section{REFERENCES}

Abdel-Khalek, A.M.; Ayyat, A. Ragab; A.I. Abd El-Lateif; Amira, M. Refaie; Kout El-kloub, M. El Moustafa and A.R. El Beltagy (2013). Effect of dietary selenium levels on growth performance and glutathione peroxidase activity of rabbits under summer season conditions. The $4^{\text {th }}$ Scientific of Animal Production Research Institute (APRI). November, Egypt, 364-369.

Aebi H. (1984). Catalase in vitro. Methods Enzymol., 105, 121-126.

Aly, A. A. (2014). Hydrochemical characteristics of Egypt western desertoases groundwater. Arabian Journal of Geosciences, 1-14.

Al-Waeli; A.; E. Zoidis; A.C. Pappas; N. Demiris; G. Zervas and K. Fegeros (2013). The role of organic selenium in cadmium toxicity: effects on broiler performance and health status. Animal, 7(3): 386393.

Antunović Z.; J. Novoselec; M. Šperanda; T. Klapec; S. Ćavar; B. Mioč; Ž. Klir; V. Pavić and R. Vuković (2014). Influence of dietary supplementation with selenium on blood metabolic profile and thyroid hormones activities in fattening lambs. Pak. Vet. J, 34(2): 224-228.

American Public Health Association (APHA) (1998). Standard Methods for the Examination of Water and Wastewater, 19th ed. American Public Health Association, Inc. New York, pp.1193.

AOAC (2000). Association of Official Analytical Chemists. Official Methods of Analysis, $17^{\text {th }}$ Ed. AOAC, Washington, DC, USA.

Arumugam, M.; A. Agarwal; M.C. Arya; Z. Ahmed (2013). Influence of nitrogen sources on biomass productivity of microalgae Scenedesmus bijugatus. Bioresource Technology, 131: 246-249.

Attia, Y.A.; A.A. Abdalah; H.S. Zeweil; F. Bovera; A.A. Tag El-Din and M.A. Araft (2010). Effect of inorganic or organic selenium supplementation on productive performance, egg quality and some physiological traits of dual purpose breeding hens. Czech Journal of Animal Science, 55: 505-519. 


\section{Hassan et al.}

Behne, D.; D. Alber and A. Kyriakopoulos (2009). Effects of long term selenium yeast supplementation on selenium status studied in the rat. Journal of Trace Elements in Medicine and Biology, 23: 258264.

Blasco, A. and J. Ouhayoun (1996). Harmonization of criteria and terminology in rabbit meat research. World Rabbit Sci., 4: 93-99.

Brown, M.W. and J.H. Watkinson (1977). Anautomated fluorimetric method for the determination of nanogram quantities of selenium. Anal. Chim. Acta, 89: 29-35.

Cases, J.; I.A. Wysocka; B. Caporiccio; N. Jouy; P. Besancon; J. Szpunar and J.M. Rouanet (2002). Assessment of selenium bioavailability from high-selenium Spirulina subfractions in seleniumdeficient rats. J. Agric. Food Chem., 50: 3867-3873.

Castellini, C.; P. Lattaioli; A. Dal Bosco and D. Beghelli (2002). Effect of supranutritional level of dietary $\alpha$-tocopherol acetate and selenium on rabbit. Theriogenology 58: 1723-1732.

Cheong, F.H.; F.Y. Kim; D. Sok; S. Hwang; J.H. Kim; H. Kim; J.H. Lee; Y. Kim and M. Kim (2010). Spirulina prevents atherosclerosis by reducing hypercholesterolemia in rabbits fed a high-cholesterol diet. J. Nutr. Sci. Vitaminology, 56: 34-40.

Colla, L.M.; A.L. Muccillo-Baisch and J.A.V. Costa (2008). Spirulina platensis effects on the levels of total cholesterol, HDL and triacylglycerols in rabbits fed with a hypercholesterolemic diet. Brazilian Arch. Biol. Techn., 51: 405-411.

Dalle Zotte, A. and Zs. Szendrö (2011). The role of rabbit meat as functional food, a review. Meat Sci., 88: 319-331.

Dalle Zotte, A.1.; A. Sartori; M. Cullere; Zs. Gerencsér; Z.s. Matics; A. Dal Bosco; M. Kovàcs and Z. S. Szendrö (2012). Dietary supplementation of spirulina (Arthrospira platensis) and thyme (Thymus vulgaris). Part 4: effect on rabbit carcass and meat quality. World Rabbit Science Association, Proceedings $10^{\text {th }}$ World Rabbit Congress - September 3 - 6, 2012- Sharm El- Sheikh - Egypt, 949953.

Dalle Zotte, A.; M. Cullere; A. Sartori; A. Dal Bosco; Zs. Gerencser; Z. S. Matics; M. Kovacs and Zs. Szendrö (2014). Effect of Dietary supplementation of Spirulina (Arthrospira platensis) and Thyme (Thymus vulgaris) on carcass composition, meat physical traits, and vitamin b12 content on growing rabbits. World Rabbit Sci., 22: 11-19.

Dokoupilová, A.; M. Marounek; V. Skřivanová and P. Březina (2007). Selenium content in tissues and meat quality in rabbits fed selenium yeast. Czech J. Anim. Sci., 52(6): 165-169.

Doucha, J.; K. Lívansk'y; V. Kotrbácek and V. Zachleder (2009). Production of Chlorella biomass enriched by selenium and its use in animal nutrition: a review. Applied Microbiology and Biotechnology, 83: 1001-1008.

Duncan, D.B. (1955). Multiple range and multiple F-tests. Biometrics, 11: 1-42.

Ebeid, T. (2009). Organic selenium enhances the antioxidative status and quality of cockerel semen under high ambient temperature. Br. Poult. Sci., 50, 641-647.

Ebeid, T.; H. Zeweil; M. Basyony and H. Badry (2012). The impact of incorporation of organic selenium into meat on growth performance, antioxidative status, and immune response in growing rabbits. World Rabbit Science Association Proceedings $10^{\text {th }}$ World Rabbit Congress - September 3-6, 2012Sharm El- Sheikh -Egypt, 861- 864.

Ebeid, T.A.; H.S. Zeweil; M.M. Basyony; W.M. Dosoky and H. Badry (2013). Fortification of rabbit diets with vitamin $\mathrm{E}$ or selenium affects growth performance, lipid peroxidation, oxidative status and immune response in growing rabbits. Livestock Science, 155: 323-331.

El-Sayed, A.B.; A.A. Abdel-Maguid and E.M. Hoballah (2011). Growth response of Chlorella vulgaris to acetate carbon and nitrogen forms. Nature and Science, 9(9): 53-58.

Fisinin, V.I.; T.T. Papazyan and P.F. Suraï (2008). Selenium in poultry nutrition. In: Surai, P.F., TaylorPickard, J. (Eds.), Current Advances in Se Research and Applications, vol. 1. Wageningen Academic Publishers, Wageningen, The Netherlands, pp. 221-261. 
Hoballah, E.; A.G. Attallah and S. Kh. Abd-El-Aal (2012). Genetic diversity of some new local strains of cyanobacteria isolated from Wadi El -Natrun, Egypt. International Journal of Academic Research, 4 (2): 314-326.

Huang, Z.; W.J. Zheng; F. Yang and B.J. Guo (2006). Chemical composition and selenium distribution in selenium enricher Spirulina platensis biomass. Chem. Natural compounds, 42(6): 636- 640.

Indira, P. and R. Biswajit (2012). Commercial and industrial applications of micro algae - A review J. Algal Biomass Utln., 3 (4): 89-100.

Iwata, K.; T. Inayama and T. Kato (1990). Effect of Spirulina Platensis on plasma lipoprotein lipase activity in fructose-induced hyperlipidemic rats. J. Nutr. Sci. Vitaminol., 36:165-171.

Kermauner, A. and A. Laurenčič (2008). Supplementation of rabbit diet with chestnut wood extract. Effect on invitro gas production from two sources of protein. In: Proceedings of the $9^{\text {th }}$ World Rabbit Congress, Verona, June10-13, 2008, pp.689-693.

Kim, M.Y.; S.H. Cheong; J.H. Lee; M.J. Kim; D.E. Sok and M.R. Kim (2010a). Spirulina improves antioxidant status by reducing oxidative stress in rabbits fed a high-cholesterol diet. J. Med. Food., 13: $420-426$.

Kim, Y.J.; W.Y. Park and I.H. Choi (2010b). Effects of dietary $\alpha$-tocopherol, selenium, and their different combinations on growth performance and meat quality of broiler chickens. Poult. Sci., 89(3): 603608.

Koracevic, D.; G. Koracevic; V. Djordjevic; S. Andrejevic and V. Cosic (2001). Method for the measurement of antioxidant activity in human fluids. J. Clin. Pathol. 54: 356-361.

Kotrbáček, V.; J. Doucha and T. Offenbartl (2004). Use of Chlorella as a carrier of organic-bound iodine in the nutrition of sows. Czech J. Anim. Sci., 49: 28-32.

Kulpys, J.; E. Paulauskas; V. Pilipavicius and R. Stankevicius (2009). Influence of cyanobacteria Arthrospira (Spirulina) platensis biomass additives towards the body condition of lactation cows and biochemical milk indexes. Agronomy Research, 7(2): 823-835.

Larsen, E. H.; M. Hansen; T. Fan and M. Vahl (2001). Speciation of selenoamino acids, selenonium ions and inorganic selenium by ion exchange HPLC with mass spectometric detection and its application to yeast and algae. J. Anal. Atom. Spectrometry, 16:1403-1408.

Lebas, F. (2004). Reflections on rabbit nutrition with a special emphasis on feed ingredients utilization. In Proceedings, $8^{\text {th }}$ World Rabbit Congress, Puebla, Mexico, September 7-10, pp. 686-736.

Lee, T.Y.; M. Tsuzuki; T. Takeuchi; K. Yokoyama and I. Karube (1995). Quantitative determination of cyanobacteria in mixed phytoplankton assemblages by an in vivo fluorimetric method. Analytica Chimica Acta, 302: 81-87.

Liu, S. M.; H. X. Sun; C. Jose; A. Murray; Z. H. Sun, J. R. Briegel; R. Jacob and Z. L. Tan (2011). Phenotypic blood glutathione concentration and selenium supplementation interactions on meat colour stability and fatty acid concentrations in Merino lambs. Meat Sci., 87: 130-139.

Machat, J.; J. Čmelík; J. Doucha and V. Otruba (2005). Selenium obohacené řasy Chlorella - frakcionace forem selenu. In: Mikroelementy 2005. 2THETA, Český Těšín, 71-75.

Mahan, D.C. (1999). Organic selenium: using nature's model to redefine selenium supplementation for animals. In Biotechnology in the feed industry (ed. TP Lyons and KA Jacques), Nottingham University Press, Nottingham, UK. pp. 523-535.

Mahmoud, K.Z. and F.W. Edens (2003). Influence of selenium sources on age related and mild heat stress-related changes of blood and liver glutathione redox cycle in broiler chickens (Gallus domesticus). Comparative Biochemistry and Physiology, 136: 921-934.

Maraschiello, C.; C. Sarraga and J.A. Garcia Regueiro (1999). Glutathion peroxidase activity. TBARS and a-tocopherol in meat from chicken fed different diets. J. Agric. Food Chem., 47: 867-872.

Marai, I.F.M.; A.A.M. Habeeb and A.E. Gad (2002). Rabbits' productive, reproductive and physiological performance traits as affected by heat stress: A review. Livest. Prod. Sci., 78:71-90. 


\section{Hassan et al.}

Marounek, M.; A. Dokoupilová; Z. Volek and I. Hoza (2009). Quality of meat and selenium content in tissues of rabbits fed diets supplemented with sodium selenite, selenized yeast and selenized algae. World Rabbit Sci., 17: 207-212.

McConnell, K.P. and J.L. Hoffman (1972). Methionine-Selenomethionine Parallels in rat liver polypeptide chain synthesis. Febs Letters, 24(1): 60-62.

McDowell, L.R. (1992). Minerals in animal and human nutrition. Academic Press, INC. Harcourt Brace Jovanvich, Publishers, San Digo, New york, Boston, 392p.

Meineri, G.; F. Ingravalle; E. Radice; M. Aragno and P.G. Peiretti (2009). Effects of high fat diets and Spirulina platensis supplementation in New Zealand White Rabbits. J. Anim. Vet. Adv., 8 (12): 27352744.

Misra, H.P. and I. Fridovich (1972). The role of superoxide anion in the autoxidation of epinephrine and a simple assay for superoxide dismutase. Journal of Biological Chemistry, 247: 3170-3175.

Nagaoka, S.; K. Shimizu; H. Kaneko; F. Shibayama; K. Morikawa; Y. Kanamaru; A. Otsuka, T. Hirahashi and T. Kato (2005). A novel protein C-phycocyanin plays a crucial role in the hypocholesterolemic action of Spirulina platensis concentrate in rats. J. Nutr., 135: 2425-2430.

Orsonneau, J. L.; P. Douet; C. Massoube; P. Lustenberger and S. Bernard (1989). An improved pyrogallol red-molybdate method for determining total urinary protein. Clin Chem., 35: 2233-2236.

Paglia, D.E. and W.N. Valentine (1967). Studies on the quantitative and qualitative characterization of erythrocyte glutathione peroxidase. J. Lab. Clin. Med., 70: 158-169.

Payne, R. L. and L.L. Southern (2005). Comparison of inorganic and organic selenium sources for broilers. Poultry Science, 84: 898-902.

Preter, F.S. (2000): Organic selenium: benefits to animal and humans, a biochemist's view. In: Proceedings of Alltech's 16th symposium. Nottingham University Press, Nottingham, pp. 205-213.

Raoof, B.; B. D.Kaushik and R. Prasanna (2006). Formulation of a low-cost medium for mass production of Spirulina. Biomass and Bioenergy, 30(6): 537-542.

Rayman, M. P. (2004). The use of high-selenium yeast to raise selenium status: how does it measure up? Brit. J. Nutr., 92: 557-573.

Richard, M. J.; B. Portal; J. Meo; C. Coudray; A. Hadjian and A. Favier (1992). Malondialdehyde kit evaluated for determining plasma and lipoprotein fractions that react with thiobarbituric acid. Clin. Chem., 38: 704-709.

Richmond, A. (1992). Mass Culture of Cyanobacteria. In: Man, N.H. and Carr, N.G. (Eds). Biotechnology Handbooks (Photosynthetic Prokaryotes). Spring-Verlag New York, LLC, PP: 181120.

Richmond, W. (1973). Determination of cholesterol in blood plasma by enzymatic colorimetric method. Clinical Chemistry, 19: 1350.

Ryu, Y.C.; M.S. Rhee; K.M. Lee and B.C. Kim (2005). Effects of different levels of dietary supplementation selenium on performance, lipid oxidation, and colour stability of broiler chicks. Poult. Sci., 84: 809-815.

Saleh, A.A.; T.A. Ebeid and Y.Z. Eid (2013). The Effect of dietary linseed oil and organic selenium on growth performance and muscle fatty acids in growing rabbits. Pak Vet J, 33(4): 450-454.

SAS (2001). User's Guide: Statistics. Version 8.2, Cary, NC, USA.

Shaltout, A.A.; M.I. Khoder; A.A. El-Abssawy; S.K. Hassan and D.L.G. Borges (2013). Determination of rare earth elements in dust deposited on tree leavesfrom Greater Cairo using inductively coupled plasma massspectrometry. Environmental Pollution, 178: 197-201.

Spears, J. W. (2003). Trace mineral bioavailability in ruminants. Journal of Nutrition, 133: 1506S-1509S.

Stadtman, E. R. and E. L. Levine (2003). Free radical-mediated oxidation of free amino acids and amino acid residues in proteins. Amino Acids, 25: 207-218. 
Steven, Lukefapor, W. D.; W. D. Hohenboken; P.R. Cheeke; N.M. Patton and W.H. Kennick (1981). Carcass and meat characteristics of Flemish giant and New Zealand white purebred and terminal cross rabbits. J. of Applied Rabbit Res. 4 (3): 66-72.

Suraï, P.F. (2002). Selenium in poultry nutrition 2.Reproduction, egg and meat quality and practical applications. World's Poult. Sci. J., 58: 431-450.

Suraï, P.F. and V.I. Fisinin (2014). Review Selenium in poultry breeder nutrition: An update. Animal Feed Science and Technology, 191: 1-15.

Umysová, D.; M. Vítová; I. Doušková; K. Bišová; M. Hlavová; M. Kížková; J. Machát; J. Doucha and V. Zachleder (2009). Bioaccumulation and toxicity of selenium compounds in the greenalga Scenedesmus quadricauda.BMC Plant Biology, 9(58): 1-16.

Wahlefeld, A.W. (1974). IN Methods of Enzymatic Analysis, HU Bergmeyer, Ed. Academic Press, New York, pp 1831-1835.

Wang,Y.B. and B.H. Xu (2008). Effect of different selenium source (sodium selenite and selenium yeast) on broiler chickens. Anim. Feed Sci. Technol., 144: 306-314.

Xin, L. I.; H. U. Hong-ying; G. Ke and Y. Ji (2010). Growth and nutrient removal properties of a freshwater microalga Scenedesmussp. LX1 under different kinds of nitrogen sources. Ecological Engineering, 36: 379-381.

Yang, Y.R.; F.C. Meng; P. Wang; Y.B. Jiang; Q.Q.Yin; J. Chang; R.Y. Zuo; Q.H. Zheng and J.X. Liu (2012). Effect of organic and inorganic selenium supplementation on growth performance, meat quality and antioxidant property of broilers. Afr J Biotechnol, 11: 3031-3036.

Zahroojian, N.; H. Moravej and M. Shivazad (2013). Effects of Dietary Marine Algae (Spirulina platensis) on Egg Quality and Production Performance of Laying Hens. J. Agr. Sci. Tech., 15: 13531360.

Zhang, Y.; S. Zhu; X. Wang; C.Wang and F. Li (2011). The effect of dietary selenium levels on growth performance, antioxidant capacity and glutathione peroxidase 1 (GSHPx1) mRNA expression in growing meat rabbits. Animal Feed Science and Technology, 169: 259-264.

Zoidis, E.; A.C. Pappas; C.A. Georgiou; E. Komaitis and K. Fegeros (2010). Selenium affects the expression of GPx4 and catalase in the liver of chicken. Comparative Biochemistry and Physiology, 155: 294-300. 


\title{
Hassan et al.
}

تأثير إضافة الطحالب الغنية بالسيلنيوم علي أداء النمو والحالة المضادة للتأكسد للأرانب تحت درجات الحرارة المرتفعة في فصل الصيف.

\author{
فوزية عامر حسان1، عصام محمد حب الله 2، محمد بسيوني3، شوقي أحمد الميداني4

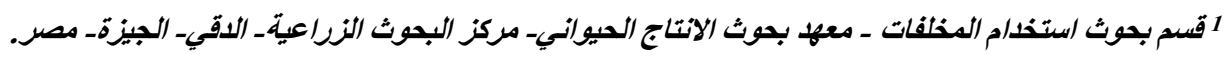

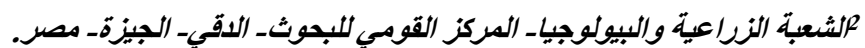

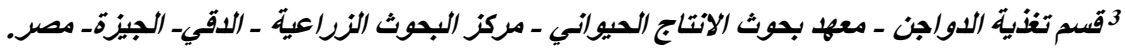 \\ 4 المركز الاقليمي للاغنية والاعلاف ـ مركز البحوث الزيراعية ـ الجبزة مصر.
}

تبحث هذه الدر اسة في تأثير مستويات مختلفة من الطحالب Spirulina الغنية بالسيلنيوم علي أداء النمو وصفات الذبيحة ومكونات

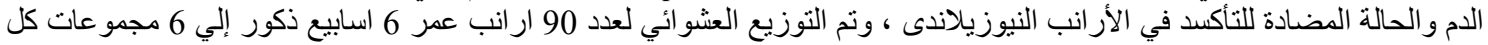

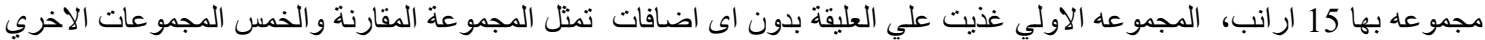

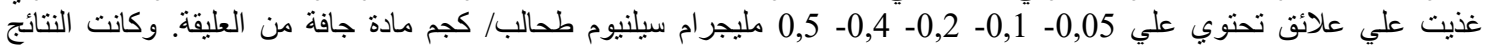
التنحصل عليها كالاتي:

ـ ـ لم يتاثر متوسط وزن الجسم النهائي ومعدل الزيادة الوزنية للجسم معنويا بإضافة الطحالب الغنية بالسيلنيوم.

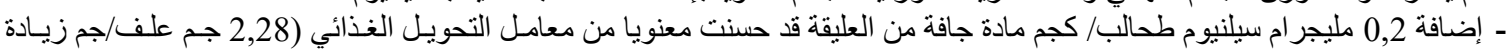

وزنية).

- إضافة الطحالب الغنية بالسيلنيوم أدت إلي زيادة معنوية في البروتين الكلي و الجلوبيولين في الدام

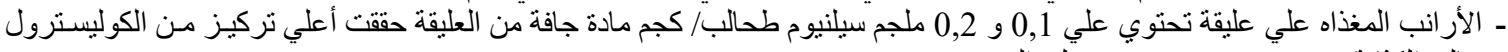

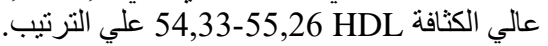
ـ لاحظّ ان إضافة الطحالب الغنية بالسيلنيوم قللت معلئ معنويا من الكوليسترول الكلي و الكوليسترول منخفض الكثافة LDL و اللبيدات الكلية في

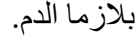

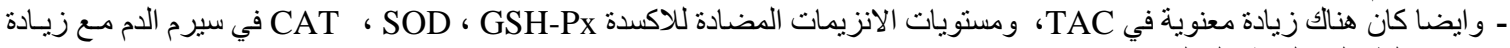
اضافه الطحالب الغنية بالسيلنيوم.

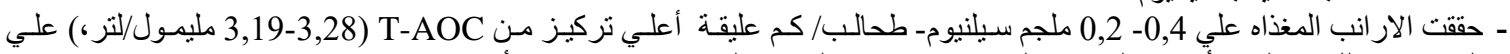

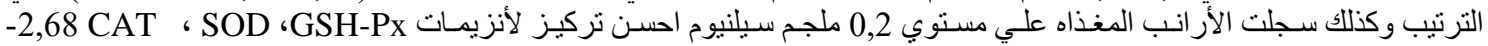
640,67-47,04 علي الترتيب.

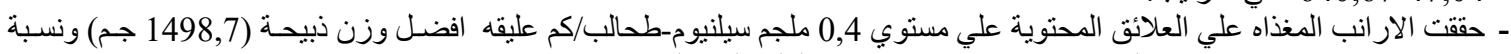

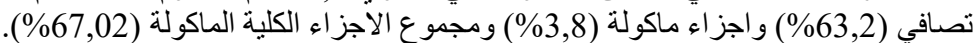

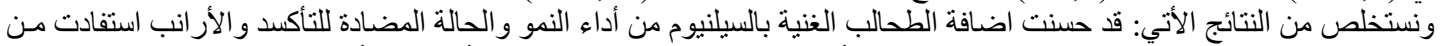

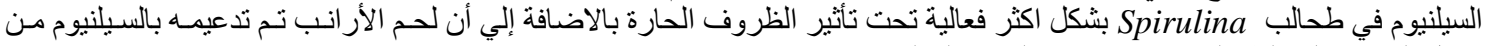
خلال التغذية علي الطحالب Spirulina الغنية بالسيلنيوم. 